\title{
Decaying Nature of Facilities and the Need for Infrastructural Development in North-east Nigeria
}

\author{
Ibrahim Baba*, Mustapha Abubakar
}

Department of Public Administration and Information and Communication Technology, Mai Idris Alooma Polytechnic, Nigeria

Copyright (C) 2015 Horizon Research Publishing All rights reserved.

\begin{abstract}
The actual point where slavery ends, there freedom is expected to begin. The state of facilities in the north eastern region of Nigeria which is sympathetic and subjecting the lives of citizens to severe hardship is not only a serious and urgent matter that demands government attention. It is also another form of slavery which people in this region are suffering from. This work examines the decaying nature of public facilities across the six states in the north-east geo-political zone of the country. It also assesses the impacts of this infrastructural decomposition on the lives of the people of the region. The work examines the needs for infrastructural development in the region. Secondary and primary sources of data collection were utilized in the study. Library based documentation analysis like textbooks, journals, newspapers, magazines and other electronic as well as print materials were consulted in the work. Personal observation visits to practically assessed facilities in the area chosen for the study within the north-east region were also embarked by the researchers. Primary source of data collection like the close ended type of questionnaire was utilized in the study. Percentage was used as the statistical tool of analysis with which data collected for this study were analyzed. The work discovered that facilities in the education, health, water, electricity and other sectors are seriously collapsing in the region. Population is growing, state efforts towards infrastructural development in the north-east are minimal and the living conditions of the people of the region are in severe state of agonies. These are some of the reasons and needs for the development of infrastructure in the north-eastern region of Nigeria.
\end{abstract}

Keywords Decaying, Development, Facilities, Infrastructures and Nature

\section{Introduction}

Education, health, water, electricity, housing, roads and other rural infrastructures in addition to food constitute the basic requirements of man in human society. Facilities that have direct impacts on the basic needs of man are not only essential but seriously required if live is to be meaningful to man in any aspects. In his capacity as community building animal, man need adequate infrastructures that would make live meaningful and comfortable for him to be able to realize his God given talents and how best to utilize them for both personal and societal development. Public facilities established in different locations across the north-eastern region of Nigeria in order to improve the living conditions of the people of the area are rotten away with time due to several reasons. In some other cases, outstanding facilities are wearing decaying features while in other, they have completely collapsed. Government efforts to arrest the nature of facilities which are rapidly decaying with time in the north-east region is minimal. The attitudes of the people of the region towards public facilities are not also impressive. Lack of maintenance on the part of the citizens coupled with poor governmental attention have continued to make the nature of public facilities still existing in the region to be discouraging. Public schools, hospitals, roads, electricity and water supply systems in the public sector across the region are rusting away. Minimal governmental attention, mishandling on the part of the people as well as the reluctances of authorities to come up with new infrastructures to replace old existing ones and reduced the over burden on old ones have put together continued to result in the decaying nature of facilities in the north-east region of Nigeria.

Geo-politically, the north-east region of Nigeria encapsulates the northern Nigeria states of Adamawa, Bauchi, Borno, Gombe, Taraba and Yobe. The region accommodates the nation's international boundaries with the Central African states of Cameroun and Chad as well as the West African state of Niger. Fulani is the major ethnic group in the region. Other tribes in the region are Kanuri, Marghi, Jukun, Kilba, Mumuye, Higgi, Babur-bura, Gamargu, Shuwa Arab, Manga, Bolewa, Bade, Karai-karai, Ngizim, Lunguda, Tiv, Chamba, etc. The major occupation of the people of the region is cattle rearing. Others engage in farming and fishing while a reasonable of others is trading (Wikipedia, 2014). The proximity of the region to other 
African countries contributes greatly to the economic potentialities and growth of the region. The north-eastern region has $13.55 \%$ of Nigeria's population with Adamawa having $2.26 \%$, Bauchi $3.34 \%$, Borno $2.97 \%$, Gombe $1.68 \%$, Taraba $1.64 \%$ and Yobe $1.66 \%$ (NPC 2006). On daily basis, the region witnesses significant inflow of people into Nigeria across the boundaries of Nigeria with Cameroun, Chad and Niger. This influx alone is also a reason to over stretch the available facilities established by the government in the region (Ndu 1999).

Nigeria by structure and political system is a federal entity with presidential system of government. There exist in the country, a decentralize system of government where political power is structurally divided between the federal, state and local governments (Ojo, 1993). Major issues on which these governments acts or operates are administratively organized under three different lists. The federal government has the exclusive power to acts on issues like power, defense, petroleum, and both internal and external affairs among others (Appadorai, 1974). On concurrent issues like education, health, water, housing, and rural infrastructural development among others both the states and federal government have the power to operates (Laski, 1986). The federal, state and local governments can operates on residual issues under which matters like feeder roads, rural power supply, culverts, bridges, boreholes, wells, hand pumps as well as transportation among other issues (Okoli, 2003). This interpretation signifies that the responsibility of developing infrastructures and guiding against their decomposition in the north-eastern region of Nigeria is that of the local, state and federal governments. But then, the way and manner which authorities are handling or dealing with the issue of infrastructural development and needs of the people in this region of the country calls for vigorous intellectual embankments to at least examined the nature of facilities in the region, the decaying level of infrastructures and reasons why development is required in this regard

\section{Problem Statement}

Several federal roads linking the major cities in the region are death traps in the eyes of many citizens of the region. Feeder roads constructed to connect the rural areas in the region are today mostly not motor able. Many communities are often disconnected from themselves and from major cities especially when the rains are around. Hospitals are not wearing the look they are often identified with. Public schools no longer provide the required conducive atmosphere needed for learning-in many, the classroom floors have broken, in some, the roof tops have been blown away by the wind while in some other cases, the structures in totality are falling from the top to the bottom-development which is putting the lives of innocent Nigerian children and future leaders as well as that of their teachers at great risk. In several other cases, infrastructures are abandoned shortly after they are started and left to rotten away without minding the resources committed to their commencement. Available sources of water supply in several communities across the region are in severe state of neglect- many localities and rural areas where majority of the people of the region resides do not even have modern source of water supply while in some other communities which are inhabited by cattle breeders-both animal and human drink from the same pond of water: development which is increasing the vulnerability of human lives to water borne diseases. In some villages and communities in the region, electricity is not available. In other cases where rural electricity is available, fuel to sustain supply is not available-making the equipment provided to supply power to suffer neglect and rust away.

From insecurity to perpetual servitude and vicious circle of unending poverty, conditions of living of the ordinary citizens in the north-eastern region of Nigeria is in a severe state of agonies and sympathies. Facilities needed for improve standard of living are inadequate. The available few are abandoned and left to rotten away due to neglect from the part of authority in some cases and careless attitudes of the citizens in others. Desertification is encroaching into the region at greater velocity due to human activities of seeking for fuel and herbs as a result of erotic power supply on one side and ill-equipped or lack of medical facilities on the other. And population is on the rise with time across the region. Reason that justify why efforts must be intensified to meet up the facility needs of the ever growing population of the north-eastern region of Nigeria. Identifying the major causes of facilities decomposition, how they affect citizens life in the region and reasons why as well as how efforts can be intensify by government and stakeholders in developing infrastructures across the north-eastern region of Nigeria so as to improve the living standard of the people of the region are some of the basic objectives which this research is designed to achieved.

\section{Objectives of the Study}

This study is designed to achieve the following objectives:

1. Examine the decaying nature of infrastructures in the north-eastern region of Nigeria.

2. Assess the level of facilities and infrastructures in the region.

3. Study the implications of poor infrastructures on the living conditions of the people of the region.

4. And to advance with recommendations on the needs for infrastructural development in the north-east region of Nigeria.

\section{Infrastructure}

The economic growth and national development of any country are dependent on the availability of functional infrastructures such as energy, roads, railways, water supply, education and a host of other amenities that converge to 
provide the required environment for the free flow of goods and services across the length and breadth of the country (World Bank 2008). The cardinal place of infrastructure in any economy can hardly be neglected. The state of infrastructures in Nigeria has remained a matter of concern given the importance of infrastructures in the economic well-being of the populace and the growth and development process of the economy. Infrastructural facilities in Nigeria are grossly inadequate to meet the need of the population (Todaro 2000, Uhunmwaungho and Ekpo 2012). Considering the nature of the proximity of north-eastern states of Nigeria to countries like Cameroun, Chad and Niger, it is expected that the economy of the region would enjoy greater growth and development. But this is not the case in this region of the country. Decaying nature of facilities ranging from collapse roads and inadequate electricity and water supply in the region are strangulating the velocity of economic growth of the region.

The cardinal place of infrastructures in any economy can hardly be neglected. Infrastructure is a non-military facility including water supply and distribution system, waste water collection and treatment facilities, transportation facilities, mass transit facilities, airports and airways facilities, resources recovery facilities, docks or airports, school buildings and solid waste disposal facilities (Mumuney, 2009). These non-military facilities are however available in communities across the north-eastern region. But then, the fact still remains clear that in some communities they are grossly inadequate or in short supply while in others, they are not even available. And in some other places where they exist, they have seriously decomposed. In other communities, they are on their way towards failures.

\section{Infrastructural Decay: Meaning, Causes and Effects}

Public facilities in the north-eastern region of Nigeria ranges from essential infrastructures put in place by governments at all levels to improve the living conditions of the people of the region as well as those initiated by the same authorities to create avenue for the promotion of well protected environment on which life would be meaningful to live. Measures adopted to strengthen rapid rural development and reduce poverty among the people through the creation of employment opportunities across the various communities in the region are also part of the meaning of public facilities in this region of country. Basic among public facilities present in the north-eastern region of Nigeria includes: amenities like water, hospitals, schools, roads, electricity, transportation facilities, communication channels, sporting and recreational facilities among others. Across the six states and eighteen senatorial districts that make up the north-eastern region of Nigeria, the nature of these facilities is discouraging. They are decaying with time. And efforts to ameliorate this situation are minimal.

The basic infrastructure in schools such as classrooms, laboratories, workshops, sporting facilities, equipment, libraries were in a state of total decay. The infrastructure and facilities remain inadequate for coping with a system that is growing at a rapid pace. The school environment is therefore generally not conducive to learning due to physical condition of most schools and lack of teaching and learning resources. The annual population growth rate estimated at 3.3 percent, contributes to the problem of the large number of children who have to be accommodated in schools (Moja, 2000). In communities across the north-eastern region of Nigeria, the population of school going children keeps increasing with time but the available number of schools keeps shrinking instead of rising. In several schools, students receive lessons standing because facilities are not sufficient. Several classes are left without sitting facilities. In classes where chairs are available, they are not even sufficient for the number of students registered in the class. Several schools which were attacked and burnt down to ashes by insurgents in the north-eastern states of Borno, Yobe and Adamawa states have not been reconstructed till date. Several public schools in the region are merely empty structures. Many do not have the required facilities for learning while in others, the facilities are available but in dilapidated nature. Most of the schools exist only in name. There are actually no structures talk less of facilitating them. Infrastructural decay therefore as Perrow (2007) argues affects the poor disproportionately such that those that are poor are forced to obtain more expensive or less safe alternative. Infrastructural decay from the submissions of Cebula (1999) has contributed to the movement of citizens from rural communities to urban centers in order to assess some of the infrastructures which they feel are abundant in the centers. This drift attributed to infrastructural decay also affects the concentration of population in rural areas across rural communities in the north-eastern region of Nigeria. Oke (1999), Okhakhu (2009) and Lewis (2008) also submits that the negative environmental effect of decay infrastructures and inadequate like air and water pollution is most evidence in densely populated inner cities where the poor are concentrated. In the ghetto settlements of major cities across the north-eastern region of Nigeria, this is part of the prevailing experiences of the people settling in the areas.

\section{Needs for Infrastructural Development}

The need for infrastructural development in developing world is critical. Untold numbers of businesses suffer from lack of reliable power for industrial processes or because they cannot get their goods to the market. At the most basic level, millions of lives are threatened every day for lack of clean water or safe sanitation. Investment in infrastructure projects forms a key part of institutional and organizational strategy (IFC 2013:1). This threat to lives is on the increase on daily basis. Available amenities are no longer meeting up with people`s demand. Infrastructures on ground are 
decaying away due to over utilization by the people and lack of maintenance from the part of the government. Living conditions are becoming miserable due to shortage of basic life improving facilities. In Bauchi, Gombe, Borno and Yobe states the stories almost similar while in Adamawa and Taraba states it worst. This call for urgent need towards infrastructural development in the entire region by stake holders and partners concerned.

Several factors accounts for the reasons and needs for infrastructural development in communities across the north-east region of Nigeria. Basic among which is the fact that the majority of the people of the region resides in the rural areas. And rural dwellers as Uchendu (2007) asserts have the tendency to shift their demand for infrastructural facilities to less qualitative and possibly less modern alternatives. These attitudes themselves such as inflicting damages on the ecosystem also have adverse effects on outstanding infrastructures. Ameliorating these impacts simply implies the development of infrastructures at the rural communities so as to prevent the people of rural areas in the north-east region from damaging the ecosystem and causing further harm on their environment and lives as well. In addition to this fact, the rise in number of persons residing in the region on daily basic equally implies that available infrastructures stand the risk of becoming inadequate with time. These again justify the basis and need to improve infrastructural development in the region.

A shortage of space currently exists in all the sub-sectors of the educational system. The expansion of the education system mainly through the introduction of universal primary education has put pressure on the education facilities that did not expand at the same rate as the school population. The existing buildings are in a state of decay with the north-eastern region of the country been the most affected zone. The existing buildings are in a state of decay due to lack of maintenance and repair. The present conditions of building impact negatively on the quality of education offered. Such conditions have encouraged a brain drain of teaching and administrative personnel out of education to other sectors of the economy. Dilapidated schools environments contribute to the high dropout of leaners from school. The amount of funding's needed for new buildings and estimated cost of the rehabilitation of the existing infrastructure is even higher. The need for provision of adequate facilities at all levels of is not only important but also urgently needed (Moja 2000).

Furthermore, additional reasons why infrastructural development is eminent in the north-eastern region of Nigeria are vividly contained in the illustrations below. Nigeria's road network is about $195,500 \mathrm{~km}$. About $32,000 \mathrm{~km}$ are state roads. About $30 \%$ of the federal roads are in deplorable state due to lack of maintenance, while as much as $75 \%$ of local roads are in poor conditions. Nigeria has a $3,505 \mathrm{~km}$ rail system which consist of 3 feet 6 inches narrow-gauge single tracks lanes running from south-west to north-east and from south-east to north-east. The rail system has remained undeveloped with outdated tracks characterized by sharp curves and severe gradients all through the routes, limiting speed to about $35 \mathrm{~km} / \mathrm{hr}$ for passenger trains. Only $50 \%$ of the 280 railway stations are functional. The signaling systems are outdated with the rolling stocks nearing a state of total collapse. Only $10 \%$ of potential passenger capacity could be attained (Mumuney 2009). This decaying railway track passes through several north-eastern Nigeria communities in Bauchi, Gombe, Yobe and Borno states. The decaying nature of this transport system is seriously affecting the economy of the region especially of states and communities where it passes through-reason why infrastructural development is needed in this aspect of transportation.

The Nigerian aviation industry was characterized by high level mismanagement. Many of the facilities at the airports were in a poor state and outdated. Many of the aircrafts in use in Nigeria did not meet the standards required by the International Civil Aviation Organization (ICAO). In addition, the arrival and departure halls at our international airports were poorly equipped while touting and pilfering remained common occurrences. Furthermore, the national carrier, Nigerian Airways Limited (now Virgin Nigeria), perform very poorly by almost all standards. The situation in the aviation industry is still the same till this moment. Again, prior to the privatization of the telecommunication industry in Nigeria, the industry was highly monopolized by the Nigeria Telecommunications Limited (NITEL). The equipment in existence at NITEL was very old and obsolete. In the area of postal services, the delivery system was very poor to the extent that the public had very poor perception of the Nigerian Postal Services. Mail theft, delay, and other irregular practices that deter customers were the practices (Todaro 2000, Uchendu 2007, Lewis 2008 and Uche 2010). Though Nitel has been privatized and Nipost is on its way towards similar experience. But the issue is that when these facilities were fully in operation, the north-east region suffered unsatisfactory service delivery because some areas within the region are inaccessible while others cannot be reached during raining season talk less of delivering services to them. Up till date the aviation facilities in the north-east region are nothing to write home about. The international airports at Maiduguri and Yola which are the oldest in the region are not fit for rendering international flights services while Bauchi, Yobe and Taraba do not even have airports at all talk less of facilitating them. The newly established one at Gombe has started decaying due to improper management and funding. The airstrip has started peeling away with potholes emerging from the shoulders of the strip and other facilities decaying down due to underutilization and poor management. There is urgent need to arrest this persisting ugly situation before it get out of hand.

\section{Research Questions}

The followings are some of the questions raised and answered by this study:

1. Does decaying facilities affect economic growth and 
development in the north-eastern region of Nigeria?

2. Is corruption responsible for the decaying nature of infrastructures in the north-eastern region of Nigeria?

3. Does the government have a role to play in infrastructural development in the north-eastern region of Nigeria?

4. Is there need for infrastructural development in the north-eastern region of Nigeria?

\section{Methodology}

This research adopted the survey design which elicits data from the sample selected for the study through various techniques such as the close ended questionnaire and unstructured interview methods. The choice of these methods and design was informed by the fact that it seeks to provide the opportunity for members of the various communities across the north-eastern region of Nigeria to express and contribute their views to the study on "The Decaying Nature of Facilities and the Need for Infrastructural Development in North-East Nigeria". Library based documentation analysis such as textbooks, journals, seminar papers, etc. sourced from the archives of different libraries and centers of research and documentation across Nigeria were also used in the study. During the cause of administering primary source of data collection instrument, the researchers also used personal observation method in assessing the nature of infrastructures in the areas visited for the study.

Table 1. Adamawa State

\begin{tabular}{|c|c|c|c|}
\hline $\begin{array}{c}\text { Senatorial } \\
\text { Districts. }\end{array}$ & $\begin{array}{c}\text { No.of } \\
\text { LGAs. }\end{array}$ & $\begin{array}{c}\text { No.of } \\
\text { Resp. }\end{array}$ & $\begin{array}{c}\text { Area of } \\
\text { Questionnaire } \\
\text { Administration }\end{array}$ \\
\hline $\begin{array}{c}\text { Adamawa } \\
\text { North }\end{array}$ & 8 & 20 & Mubi \\
\hline $\begin{array}{c}\text { Adamawa } \\
\text { Central }\end{array}$ & 6 & 15 & Yola \\
\hline $\begin{array}{c}\text { Adamawa } \\
\text { South }\end{array}$ & 7 & 15 & Numan \\
\hline Total Per Unit & 21 & 50 & 3 Selected Areas \\
\hline
\end{tabular}

Source: Field Survey (2014).

Table 2. Bauchi State

\begin{tabular}{|c|c|c|c|}
\hline $\begin{array}{c}\text { Senatorial } \\
\text { District }\end{array}$ & $\begin{array}{c}\text { No. of Local } \\
\text { Governments }\end{array}$ & $\begin{array}{c}\text { No. of } \\
\text { Respondents }\end{array}$ & $\begin{array}{c}\text { Area of } \\
\text { Questionnaire } \\
\text { Administration }\end{array}$ \\
\hline $\begin{array}{c}\text { Bauchi } \\
\text { North }\end{array}$ & 9 & 20 & Azare \\
\hline $\begin{array}{c}\text { Bauchi } \\
\text { Central }\end{array}$ & 5 & 15 & Darazo \\
\hline $\begin{array}{c}\text { Bauchi } \\
\text { South }\end{array}$ & 7 & 15 & Bauchi \\
\hline $\begin{array}{c}\text { Total per } \\
\text { unit }\end{array}$ & 21 & 50 & 3 Selected Areas \\
\hline
\end{tabular}

Source: Field Survey (2014)
Table 3. Borno State

\begin{tabular}{|c|c|c|c|}
\hline $\begin{array}{c}\text { Senatorial } \\
\text { District }\end{array}$ & $\begin{array}{c}\text { No. of Local } \\
\text { Governments }\end{array}$ & $\begin{array}{c}\text { No. of } \\
\text { Respondents }\end{array}$ & $\begin{array}{c}\text { Area of } \\
\text { Questionnaire } \\
\text { Administration }\end{array}$ \\
\hline Borno North & 10 & 20 & Monguno \\
\hline $\begin{array}{c}\text { Borno } \\
\text { Central }\end{array}$ & 8 & 15 & Maiduguri \\
\hline Borno South & 9 & 15 & Biu \\
\hline $\begin{array}{c}\text { Total per } \\
\text { unit }\end{array}$ & 27 & 50 & 3 Selected Areas \\
\hline
\end{tabular}

Source: Field Survey (2014)

Table 4. Gombe State

\begin{tabular}{|c|c|c|c|}
\hline $\begin{array}{c}\text { Senatorial } \\
\text { District }\end{array}$ & $\begin{array}{c}\text { No. of Local } \\
\text { Governments }\end{array}$ & $\begin{array}{c}\text { No. of } \\
\text { Respondents }\end{array}$ & $\begin{array}{c}\text { Area of } \\
\text { Questionnaire } \\
\text { Administration }\end{array}$ \\
\hline $\begin{array}{c}\text { Gombe } \\
\text { North }\end{array}$ & 5 & 20 & Gombe \\
\hline $\begin{array}{c}\text { Gombe } \\
\text { Central }\end{array}$ & 2 & 15 & Kumo \\
\hline $\begin{array}{c}\text { Gombe } \\
\text { South }\end{array}$ & 4 & 15 & Kaltungo \\
\hline $\begin{array}{c}\text { Total per } \\
\text { unit }\end{array}$ & 11 & 50 & 3 Selected Areas \\
\hline
\end{tabular}

Source: Field Survey (2014)

Table 5. Taraba State

\begin{tabular}{|c|c|c|c|}
\hline $\begin{array}{c}\text { Senatorial } \\
\text { District }\end{array}$ & $\begin{array}{c}\text { No. of Local } \\
\text { Governments }\end{array}$ & $\begin{array}{c}\text { No. of } \\
\text { Respondents }\end{array}$ & $\begin{array}{c}\text { Area of } \\
\text { Questionnaire } \\
\text { Administration }\end{array}$ \\
\hline $\begin{array}{c}\text { Taraba } \\
\text { North }\end{array}$ & 6 & 20 & Jalingo \\
\hline $\begin{array}{c}\text { Taraba } \\
\text { Central }\end{array}$ & 5 & 15 & Bali \\
\hline $\begin{array}{c}\text { Taraba } \\
\text { South }\end{array}$ & 5 & 15 & Wukari \\
\hline $\begin{array}{c}\text { Total per } \\
\text { unit }\end{array}$ & 16 & 50 & 3 Selected Areas \\
\hline
\end{tabular}

Source: Field Survey (2014).

Table 6. Yobe State

\begin{tabular}{|c|c|c|c|}
\hline $\begin{array}{c}\text { Senatorial } \\
\text { District }\end{array}$ & $\begin{array}{c}\text { No. of Local } \\
\text { Governments }\end{array}$ & $\begin{array}{c}\text { No. of } \\
\text { Respondents }\end{array}$ & $\begin{array}{c}\text { Area of } \\
\text { Questionnaire } \\
\text { Administration }\end{array}$ \\
\hline $\begin{array}{c}\text { Yobe NE } \\
\text { (Zone A) }\end{array}$ & 7 & 20 & Damaturu \\
\hline $\begin{array}{c}\text { Yobe NW } \\
\text { (Zone C) }\end{array}$ & 6 & 15 & Gashua \\
\hline $\begin{array}{c}\text { Yobe South } \\
\text { (Zone B) }\end{array}$ & 4 & 15 & Potikum \\
\hline $\begin{array}{c}\text { Total per } \\
\text { unit }\end{array}$ & 17 & 50 & 3 Selected Areas \\
\hline
\end{tabular}

Source; Field Survey (2014)

Note: The Lead Researcher administered 150 questionnaires in 9 locations (Azare, Darazo, Bauchi, Gombe, Kumo, Kaltungo, Jalingo, Bali and Wukari) while the Co-Researcher also administered 150 in 9 locations at Gashua, Damaturu, Potiskum, Monguno, Maiduguri, Biu, Mubi, Yola and Numan. All the questionnaires administered by the researchers were completely retrieved back and analyzed.

In order to carry out the research, a total of 300 
questionnaires were self-administered among the people of the north-eastern region of Nigeria randomly selected by the researchers. The north-east region was collapsed into six states and eighteen senatorial districts by the researchers. In each state, 50 questionnaires were administered to 50 respondents by the researchers. In each senatorial district, 15 questionnaires were administered in zones with similar number of local government areas while 20 questionnaires were administered in senatorial zones with the highest number of local government areas. The questionnaires were administered at the headquarters of one selected local government areas each in the eighteen senatorial zones in the region. See the table 1-6.

\section{Data Presentation}

In order to carry out this research, a total of 300 questionnaires were self-administered by the researchers amongst the people of the 18 senatorial districts and 6 states of the north-eastern region of Nigeria. However, all the questionnaires were retrieved which represent hundred percent.

\section{Analysis of Interpretation}

Percentage was used to analyze response to questionnaire administered and retrieved by the researchers. These were also tabulated and interpreted as can be seen below:

Table 7. Question 1- Are there actually facilities on ground in the north-east region of Nigeria?

\begin{tabular}{|c|c|c|}
\hline Options & No. of Respondents & $\begin{array}{c}\text { Percentage } \\
\text { Responses }\end{array}$ \\
\hline Yes & 300 & $100 \%$ \\
\hline No & 0 & $0 \%$ \\
\hline Total & 300 & $100 \%$ \\
\hline
\end{tabular}

Source: Field Survey (2014)

Table 7 clearly shows that $100 \%$ of the respondents involved in this study agreed that there are actually facilities on ground in various communities across the north-eastern region of Nigeria

The facilities on ground according to $88.67 \%$ of the respondents are decaying while $13.33 \%$ of them as table 8 shows do not agree that facilities on ground across the region are rotten away.
Table 8. Question 2- Do you agree that facilities on ground in the region are decaying?

\begin{tabular}{|c|c|c|}
\hline Options & No. of Respondents & $\begin{array}{c}\text { Percentage } \\
\text { Responses }\end{array}$ \\
\hline Yes & 260 & $86.67 \%$ \\
\hline No & 40 & $13.33 \%$ \\
\hline Total & 300 & $100 \%$ \\
\hline
\end{tabular}

Source: Field Survey (2014)

Table 9. Question 3- Does decaying facilities affect economic growth and development in the region?

\begin{tabular}{|c|c|c|}
\hline Options & No. of Respondents & $\begin{array}{c}\text { Percentage } \\
\text { Responses }\end{array}$ \\
\hline Yes & 250 & $83.33 \%$ \\
\hline No & 50 & $16.67 \%$ \\
\hline Total & 300 & $100 \%$ \\
\hline
\end{tabular}

Source: Field Survey (2014)

Economic growth and development of the north-east region of Nigeria according to $83.33 \%$ of the respondents is been affected by the decaying nature of facilities in the region. But table 9 also shows that $16.67 \%$ of the respondents disagreed that the region's economic growth and development is been threaten or affected by the decaying nature of facilities the region is suffering from.

Table 10. Question 4- Is corruption a responsible factor for the decaying nature of facilities in the region?

\begin{tabular}{|c|c|c|}
\hline Options & No. of Respondents & $\begin{array}{c}\text { Percentage } \\
\text { Responses }\end{array}$ \\
\hline Yes & 200 & $66.67 \%$ \\
\hline No & 100 & $33.37 \%$ \\
\hline Total & 300 & $100 \%$ \\
\hline
\end{tabular}

Source: Field Survey (2014)

Table 10 shows that $66.67 \%$ of the respondents agreed that corruption especially on the part of the public officers and political elites is responsible for the decaying nature of facilities in the north-eastern region of Nigeria while $33.37 \%$ disagreed with this view.

Table 11. Question 5- Is there any need for infrastructural development in the region?

\begin{tabular}{|c|c|c|}
\hline Options & No. of Respondents & $\begin{array}{c}\text { Percentage } \\
\text { Responses }\end{array}$ \\
\hline Yes & 300 & $100 \%$ \\
\hline No & 0 & $0 \%$ \\
\hline Total & 300 & $100 \%$ \\
\hline
\end{tabular}

Source: Field Survey (2014) 
However, $100 \%$ of the respondents all agreed that there is serious and urgent need for infrastructural development in the north-eastern region of Nigeria.

Table 12. Question 6- Does the government have a role to play in infrastructural development in the region?

\begin{tabular}{|c|c|c|}
\hline Options & No. of Respondents & $\begin{array}{c}\text { Percentage } \\
\text { Responses }\end{array}$ \\
\hline Yes & 220 & $73.33 \%$ \\
\hline No & 80 & $26.67 \%$ \\
\hline Total & 300 & $100 \%$ \\
\hline
\end{tabular}

Source: Field Survey (2014)

Government at local, state and federal levels according to $73.33 \%$ of the respondents have active roles to play in infrastructural development in the north-eastern region of Nigeria. But then, table 12 also shows that $26.67 \%$ of them disagreed with the view that government has a role to play in infrastructural development in the region.

\section{Conclusions and Recommendations}

Based on the data which were collected from the respondents chosen and involved in this study from the 18 senatorial districts of the north-eastern region of Nigeria and analyzed by the researchers, the followings findings were made;

1. There are public facilities scattered across the various communities within the north-eastern region of Nigeria.

2. Some of these facilities are rotten away due to negligence on the part of government in one hand and public attitudes on the other.

3. Decaying facilities or infrastructural decay is pulling down and back, the economic development and growth of the people of the north-east region of Nigeria.

4. Corruption among the people especially public officers which is resulting in shortage of fund to develop facilities and maintain existing ones is contributing to the prevailing decomposition of infrastructures across the region.

5. There is urgent need for infrastructural development in the north-east region of Nigeria where $13.55 \%$ of the nation's population according to NPC (2006) dwells.

6. The federal government of Nigeria as well as the state and local governments in the north-east region have important roles to play in infrastructural development in the region.

However, in as much as the government is expected to actively involve itself in infrastructural development in this sensitive region of the country, other stakeholders or development partners must not only demonstrate their willingness to participate in this transformative process. They must also be willing to contribute expertise and funds towards the cause of infrastructural development in the north-eastern region of Nigeria.

Finally, the followings are the recommendations of this study:

1. There is urgent need for government to commence on rapid infrastructural development in communities across the north-east region of Nigeria. Schools, hospitals, roads, water supply system, electricity projects that are collapsing should be rehabilitated. New ones should also come up to reduce the burden and over utilization existing ones are suffering from. In developing infrastructures to supplement the over utilization of existing facilities, standard must not be compromise at all cost. Infrastructures that are likely to withstand pressure and text of time must be developed as against sub-standard ones which can easily rotten and decomposed away quickly.

2. Improve communication channel among the people of the north-east region should be intensified. This can easily be achieved through the construction of several roads to connect the various communities in the region together. Finding shows that majority of the people of the region dwell in the rural areas which are not accessible especially when the rains are here. There is no how life can be meaningful without standard connectivity and linkage promoted through the constructions of motor able roads to link people together. Collapsed culverts. Decomposed rural bridges as well as rusticated rural electrification projects should be resuscitated. Government must be willing to commit funds and the people-their time and other resources through community development initiatives are also needed to enhance infrastructural development in the region.

3. Governmental policies in the area of infrastructural development should be designed to create conditions that would stimulate and encourage foreign partnership in the development of infrastructures in the north-east region of the country and Nigeria as a whole. Policies that would encourage development partners like World Bank, UNICEF, UNESCO, as well as other private organizations to participate in the development of infrastructures in the region are required.

4. Poverty reduction and if possible eradication should be promoted and encouraged among the people of the north-east region of Nigeria. This can be made possible by adopting poverty alleviation policies and programs that would empower the people in the north-east region to be able to be self-reliant to an extent that they would constitute any threat to their own environment through their conducts of destroying the ecosystem that protect their environment and health at the same time. The establishment of light industries at the rural areas is also required to prevent drift to urban centers and constitute threat or burden to 
the inadequate infrastructures there. This would also result to job available at the rural communities across the region.

5. Corruption must be shunned by political leaders and public office holders. Resources provided for infrastructural development must be committed to the course of developing facilities. Tribalism, nepotism, favoritism, religious and other sentiments must be prevented at all cost. Political elites, public office holders and the people of the region must be willing to be patriotic and demonstrate this in their efforts towards infrastructural development as well as the economic and general development of their region and nation in general.

\section{Acknowledgements}

This research is supported by the Tertiary Education Trust Fund (TETF) in the 2012/2013 intervention (Research).

\section{Appendix 1}

\section{Introductory Letter}

Mai Idris Alooma Polytechnic

P. M. B. 1020, Geidam, Yobe State,

Nigeria.

May 22, 2014

Dear Respondent,

We are senior academic staff of the above mentioned institution carrying out research on "The Decaying Nature of Facilities and the Need for Infrastructural Development in the North-East Region of Nigeria". We shall be appreciative if you can assist us by providing your humble response to the questions attached. All information given by you shall be treated with maximum confidentiality and for the purpose of this research alone.

Thank you.

ours sincerely, Ibrahim Baba and Mustapha Abubakar.

\section{Appendix 2}

\section{The Questionnaire}

Respondent Data

Gender:

Marital Status:

Age:

Occupation:

Instructions:
Please do not make comment or suggestion on the questionnaire. Only give your opinion by choosing one from options and alternative answers given.

The Questions;

Are there actually public facilities on ground across the north-east region of Nigeria?

\section{/ YES / /NO/}

Do you agree that facilities on ground in the region are seriously decaying?

/YES/

/NO/

Does decaying facilities affect economic growth and development in the region?

/YES/

/NO/

Is corruption a responsible factor for the decaying nature of facilities in the region?

\section{/YES/}

/NO/

Is there any need for infrastructural development in the region?

/YES/

/NO/

Does the government have a role to play in the development of infrastructures in the region?

/YES/

/NO/

\section{REFERENCES}

[1] Appadorai A. A. (1974): The Substance of Politics. New Delhi: Oxford University Printing Press.

[2] Cebula R. C. (1999): The Determinants of Human Migration in Africa. Ibadan: University Printing Press.

[3] IFC (2013): Infrastructure in Africa (Regions). International Finance Corporation. World Bank Group.

[4] Laski H. J. (1986): A Grammar of Politics. London: Allen and Unwin.

[5] Lewis D. (2008): Infrastructural Decay in Nigeria. Wikipedia catched of June 2011.

[6] Moja T. (2000): Nigerian Education Sector Analysis: An Analytical Synthesis of Performance and Main Issues. Ibadan: University Printing Press.

[7] Mumuney Q. A. (2009): "Infrastructural Decay and National Development-The YRole of Banks". In Social Science Research Network July 6, 2009. PP 1-7.

[8] Ndu M. F. (1999): Regional and Human Geography of West Africa. London: Macmillan Press.

[9] NPC (2006); National Population Census and Head Counts. Abuja: Federal Ministry of Information Press.

[10] Ojo O. O. (1993); Government for Senior Secondary Schools. Lagos: Evans Brothers Publishing Company.

[11] Oke A. A. (1999): "Integrated Rural Development, Meaning, Scope and Components". Paper presented at the Conference on Integrated Rural Development and Women in Development, Benin City, Nigeria.

[12] Okhakhu P. A. (2009): "The Socio-Economic Implication of Infrastructural Decay in Nigeria". Being a Paper Presented at Seminar on Infrastructural Development at the Department of 
Business Administration, University of Benin, Nigeria.

[13] Okoli P. F. C. (2003): Foundations of Government and Politics. Onitsha, Nigeria: Africana First Printing (AFP) Limited.

[14] Perrow C. (2007): Complex Organizations: A Critical Essay. Glenview III, Scott, Foresman Publication Company.

[15] Todaro M. P. (2000): Economic Development and Growth Euphoria. Ibadan: University Printing Press.

[16] Uche N. N. (2010): Readings in Nigeria Rural Sociology. Ibadan: University Printing Press.
[17] Uchendu K. (2007): State of Infrastructure in Nigeria: Stylized facts Wikipedia, catched http://www.nigerianews.com/perspective-3.htm.

[18] Uhunmwaungho S. O. and Ekpo C. (2012): "Analysis of Socio-Political Implication of Infrastructural Decay in Nigeria”. In African Research Review Journal Vol 6 (4) serial No. 27, October 2012. PP 40-58.

[19] Wikipedia(2014):Catchedhttp://www.//.allafrica.com/stories/ 200708240645.

[20] World Bank (2008); The Importance of Infrastructure to Economic Development. An example from China 